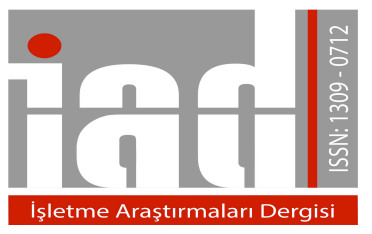

Journal Of

Business Research

Turk

www.isarder.org

\title{
Okul Yöneticilerinin Liderlik Davranışları, Performans Uygulamaları ve Kurumsallaşmaya İlişskin Öğretmen Görüşlerinin Çeşitli Değişkenler Açısından İncelenmesi \\ Leadership Behaviors of School Administrators, Performance Practices and Examination of Teacher Views on Institutionalization in Terms of Various Variables
}

\author{
Erdal ŞEN \\ İstanbul Gelişim Üniversitesi \\ İktisadi, İdari ve Sosyal Bilimler Fakültesi \\ İstanbul, Türkiye \\ orcid.org/0000-0003-1179-7214 \\ esen@gelisim.edu.tr, sen@senizm.com
}

\author{
Hülya ATEŞOĞLU \\ İstanbul Gelişim Üniversitesi \\ Meslek Yüksekokulu \\ İstanbul, Türkiye \\ orcid.org/0000-0003-2116-3821 \\ hatesoglu@gelisim.edu.tr
}

\section{Seda AKDOĞAN}

orcid.org/000-0002-4944-5671

sedaakdoğan87@hotmail.com

\begin{abstract}
Özet
Küreselleşme, iletişim teknolojilerindeki hızlı değişim, uluslararası rekabet ve tüketici beklentilerindeki değişim gibi birçok gelişme, diğer bütün kurumları olduğu gibi eğitim kurumlarını da büyük ölçüde etkilemiştir. Tüm bu gelişmeler; okulların daha kreatif, etkili, donanımlı ve ihtiyaçlara hızla cevap verebilecek nitelikte olmasını gerektirmektedir. Bunun için de okuldaki personelin, örgütsel amaçlar etrafinda birleşmesi, örgütsel bağl1lık seviyelerinin yüksek olması hatta kendilerini kuruma adamaları büyük önem taşımaktadır. Bu çalışma; okul yöneticilerinin liderlik davranışları, performans uygulamaları ve kurumsallaşmaya ilişkin öğretmen görüşlerinin çeşitli değişkenler açısından değerlendirerek, sonuçların neler olduğunun tespitine yönelik, alan uygulamalı bir çalışmadır. Araştırma için hazırlanan ölçekler, özel bir eğitim kurumunun İstanbul'daki tüm şubelerinde görev yapan toplam 133 öğretmen ve yöneticisine uygulanmıştır. Katılımcıların cevapları dikkate alınarak SPSS 15.0 istatistik programında veriler analiz edilmiş olup, sonuç ve önerilerin geliştirilmesiyle araştırma tamamlanmıştır. Araştırma sonucunda yaş, cinsiyet, eğitim durumu, hizmet süresi gibi çeşitli değiş̧kenler açısından öğretmen görüşlerinin liderlik, performans uygulamaları ve kurumsallaşma algısı üzerinde farklılık gösterdiği tespit edilmiştir.
\end{abstract}

Anahtar Kelimeler: Liderlik, Performans, Kurumsallaşma, Okul Yönetimi 


\begin{abstract}
Many developments, such as globalization, rapid change in communication technologies, international competition and consumer expectations have influenced educational institutions as well as all other institutions. All these developments; forced schools need to be more creative, effective and capable of responding fastly to needs. For this main reason, it is of great importance that the personnel in the school are united around the organizational goals and that the students themselves are high in their devotion and commitment. This work; is a field-based study of school administrators' leadership behaviors, performance practices, and teacher involvement in institutionalization to determine what the consequences are in terms of various variables. The scales prepared for the research were applied to a total of 133 teachers and administrators working in all branches of a private educational institution in Istanbul. Considering the answers of the participants, the data were analyzed in the SPSS 15.0 statistical program, the hypotheses were tested and the research was completed by developing the results and recommendations. As a result of the research, it has been determined that the opinions of teachers differ according to various variables like age, gender, education status, duration of service on the perception of leadership, performance practices and institutionalization variables.
\end{abstract}

Keywords: Leadership, Performance, Institutionalization, School Management

\title{
1.Giriş
}

Günümüzde ekonomik ve teknolojik gelişmelere paralel olarak büyük toplumsal değişim ve dönüşümler yaşanmaktadır. İçinde bulunduğumuz dönem tanımlanırken; Bilgi Çağı, İnternet Çağı, Bilişim Çağı, Hız Çă̆ı, Uzay Çağı, Endüstri 4.0 Çağı, Endüstri 5.0 Çağı, Nano-teknoloji Çağı, Gen-bilim Çağı, Yeni Ekonomi Çağı, Ben Çağı ve benzeri birçok farklı ve yeni kavram kullanılmaktadır. Yeni döneme geçişle birlikte, hızlı teknolojik ilerlemeler ve değişimlerden kaynaklanan toplumsal, ekonomik, siyasal, askeri ve sosyo-kültürel alanlarda köklü ve etkili değişimler her geçen gün gözlenmektedir (Şen 2017:150).

$\mathrm{Bu}$ sürecin en önemli etkenlerinden biri olan insanın; başta teknoloji olmak üzere; ilgili tüm değişkenlerle olan ilişkisinin değerlendirilmesi ve yorumlanması kaçınılmaz bir gerçeklik olarak ortaya çıkmaktadır (Şen, 2017:251). Tüm kurumları etkileyen bu süreç eğitim kurumları ve yapılarını da etkilemektedir. Bu süreç, okulların yeniliklere cevap verebilecek nitelikte olmasını gerektirmektedir. Bunun için de okuldaki personelin, örgütsel amaçlar etrafında birleşmesi, örgütsel bağl1lık seviyelerinin yüksek olması hatta kendilerini kuruma adamaları büyük önem taşımaktadır. Bu noktada; okul yöneticilerinin de rolleri, görevleri ve yöneticilerden beklenenler giderek daha karmaşık bir hal almaktadır. Hızla değişen bir ortamda okulları başarılı bir biçimde gelecek yüzyıla taşıyacak yöneticilerin; okulu, içinde bulunulan toplumu ve öğrenci, öğretmen, veli, idari personel de dahil olmak üzere iç ve dış paydaşları birey olarak çok iyi anlamaları, okulun başarılı olabilmesi için liderlik yapmaları ve sürekli olarak kendilerini geliştirmeleri beklenmektedir. Okul yönetiminde ortaya çıkan pek çok sorunun ortadan kaldırılması ve okul eğitiminin daimi geliştirilmesi için etkili, üretici, vizyoner, motive edici, bilgili ve ilkeli liderlerin öncülük ettiği yöneticilerin varlığ önemlidir. 
Carmeli ve diğerleri (2006a) ve Carmeli ve diğerleri (2006b) yaptıkları araştırmalarda, kurum yöneticisinin liderlik davranışlarının, çalışanların yenileşmeye ilişsin davranışlarını etkilediğini, üst yönetimin liderlik davranışlarının, kurumun performansını artırdığını saptamışlardır.

Okul yöneticileri, ögretmenleri desteklemeli ve kendilerini geliştirmeleri için ortam yaratmalıdırlar. Bu şekilde öğretmenlerin becerilerini ortaya çıkararak, yüksek performans sergilemeleri sağlanabilir. Öğretmenler, müdürlerini lider olarak benimsemişse; çalışma motivasyonları, işten aldıkları doyum ve okulla bütünleşmeleri kolayca gerçekleşebilir (Şişman,2004).

Öğretmenlerin performanslarının yüksek olabilmesi için; performans değerlemesi çalışmaları kapsamında, durumları objektif bir biçimde değerlendirilmeli ve performans geliştirici faaliyetler üretilmelidir. "Öğrenme koşullarının iyileştirilmesi ve öğretmenlerin geliştirilmesi ancak güçlü bir örgütsel liderlik ve kurumsal destek ile başarıya ulaşabilir" diyen Karip ve Köksal'ın (1996) bu düşüncesini “Liderlik öğrenci başarısına ve diğer örgütsel amaçların gerçekleştirilmesine katkısı bakımından etkili okul kavramının ayrılmaz bir parçası olarak görülmektedir" diyerek Yılmaz (2010) desteklemektedir (Y1lmaz, 2010: 27-28, Şama, Kolamaz, 2011:319-321).

\section{Kuramsal Çerçeve}

Günümüz dünyasında birçok değişkene bağlı nedenlerden kaynaklı, insan ve kurumlara dair her şey hızlı bir biçimde değişip, dönüşmektedir (Şen,2017:150). Bu dönüşüm süreci eğitim kurumlarında da kendini hissettirmektedir. Küreselleşen dünyanın gereklerini karşılayabilmede başarılı olabilmek için eğitim açısından göz önünde tutulması gereken bazı önemli unsurlar bulunmaktadır (Çalık ve Sezgin, 2005: 61):

1. Eğitim yaşam boyu süren bir etkinlik olmalıdır.

2. Eğitim, her zaman, her yerde ve yaşamın her alanında olmalıdır.

3. Eğitim, eleştirel düşünmeye, iletişime ve problem çözme becerilerine odaklanmalıdır.

4. Öğrenme, toplumun gelişmesinde önemli bir etken olduğu için, eğitim toplumsal gelişmeye yatırım niteliğinde olmalıdır.

5. Eğitim sistemi, öğrencilere küresel bir vatandaşlık anlayışı kazandırmalıdır.

6. Eğitim, bireyler ve örgütler arasında ortaklık ilişkisini sağlamalıdır.

Eğitim kurumları hem kendi aralarında hem de işletme, sanayi ve kamu kurumları arasında ortaklık ve işbirliği sağlanması yönünde çalışmalar yapmalıdır. Bu yönden, bir eğitim kurumu yalnızca kendi uzmanlık alanında tek başına kalmamalı, içinde bulunduğu toplumun ve dünyanın değişen ve dönüşen ihtiyaçlarına cevap vermek zorundadir.

Küreselleşen dünyada eğitim, sürekli öğrenmeyi, bilgiyi bilmeyi, bilgili olmayı, bilgiyi üretmeyi, bilgi ile yaşamayı sağlayan bir süreçtir. Küreselleşme sürecindeki eğitim yöneticisi ise, birey-toplum-çevre uyumunu gözeten, güven ilkesini benimseyen biri olarak görülmelidir (Doğan, 2002:95). 
Öte yandan; hem özel hem de kamu kurumlarında, kurumsal yönetişimin özü sadece iktidar olmak değil, etkili karar almayı sağlamaktan geçmektedir. Bu yüzden, kurumlar hakkında karar verici durumunda olan yöneticilerin alınacak olan kararlarda çalışanların katılımlılarına önem vermeleri gerekmektedir. Öğretim kurumlarındaki yöneticilerin, çalışanların ve öğrencilerin katılımlarının sağlanması tüm ilgili taraflara önemli yararlar sağlayabilecektir (Apak vd.,2013:6-7).

Eğitim yönetimini diğer kurumların yönetiminden farklı kılan eğitimin kendine özgülüğüdür. Okul yönetimi, eğitim yönetiminin bir alt uygulama alanıdır. Eğitim yönetimi, eğitime makro düzeyde, okul yönetimi ise mikro düzeyde yaklaşmaktadır. Yani eğitim yönetimi sistem ile ilgiliyken okul yönetimi okul düzeyinde etkililikle ilgilenmektedir. Sonuç olarak, eğitim örgütleri de diğer örgütler gibi bazı hedef ve amaçlara sahiptir. Fakat bu amaç ve hedefler diğerlerinden farklı olarak soyut hedef ve amaçlardır. Okul yönetiminde liderlik de okul yöneticisinin bu amaç ve hedeflere ulaşmada çalışanları etkilemede kullanılabileceği güçler olarak tanımlanabilir (Kılınçarslan,2013:24-25).

Okul müdürleri; öğretmenleri güdülemede, örgütsel amaçlar etrafında birleştirmede, kendilerini okula adamalarını sağlamada ve en önemlisi de eğitimöğretim sürecini geliştirmede etkilerini kullanmak zorundadır (Kılınçarslan,2013:1). İş yaşamında başarının en önemli kaynaklarından biri de elde edilen doğru verilerin en etkin, etkili ve verimli bir biçimde kullanılarak yorumlanması ve alınan kararların bu bilgiler 1şı̆̆ında hayata geçirilmesi gerekliliğidir (Korkmaz vd., 2015:17).

Okul müdürünün okulda lider olarak kabul edilmesi; grubun amaca ulaşmasındaki iletişim becerisi, bilgisi, sorunları çözmedeki yaklaşımı, kararlılığı, çok yönlü düşünebilmesi, anlama, açıklama, yordama ve yargılama özelliklerinin bütünleştiği yönetsel ve kişisel etkisinin okuldaki öğretmenler, öğrenciler ve diğer bireyler tarafından benimsenmesine bağlıdır. Yöneticinin lider olarak kabul edilmesi için yönettiği personelin düşüncelerini, duygularını, değer yargılarını, inançlarını ve davranışlarını etkilemede ve yönlendirmede alışılmış uygulamaları ve belli otorite kaynaklarını aşabilmesi gerekir (Erkuş, 1997: 12). Eğer bunları gerçekleştiremiyorsa okul müdürü sadece yönetici olarak nitelendirilebilir. Lider bir yönetici örgütün işleyiş doğrultusuna ilişkin özel bir bilinç ve anlayışa sahip olan kişidir (Bursalıoğlu, 1998: 209). Müdürlerin görevi çok önemli olmasına rağmen Türkiye'de okul müdürü atamalarında gerekli hassasiyet gösterilmemektedir. Atamalardan sonra kısa süreli hizmet içi eğitimle yetinilmekte olup bu eğitimler müdürler için yeterli gelmemektedir. Halbuki okul yöneticilerinin 2000'li yılların gerektirdiği işbirliğinin teşviki, öncelik kullanma, başkalarının cesaretlendirilmesi ve profesyonel yöneticiliğin ve problem çözme kapasitesinin geliştirilmesi gibi yeni akımlar konusunda bilgilendirilmeleri gerekir. Bunların yanı sıra çağın gelişen ve değişen şartlarına uyum sağlama özelliği de kazandirılmalıdır (Korkmaz, 2005: 405).

Thompson (1999:107), ABD'de okul yöneticisi yetiştirme konusunda oluşturulan bir komisyon raporunda okul liderleri için altı temel standart belirlemiştir (Akt: Çelik, 2001:408). Bunlar:

- Bir öğrenme vizyonunun oluşturulmasını, uygulanmasını ve paylaşılmasını kolaylaştırmak ve bu konuda öğretmenleri desteklemek, 
- Destekleyici ve insan kaynaklarını geliştirici bir okul kültürü oluşturmak ve öğrencinin öğrenmesi için daha esnek öğretim programı geliştirmek,

- Okuldaki bütün kaynakları etkili öğrenme çevresinin oluşturulması doğrultusunda kullanmak,

- Toplumsal kaynakları, toplumun çok farklı ilgi ve ihtiyaçlarını karşılamak amaciyla kullanmak, okul ve çevreyle işbirliği kurmak,

- Davranışlarda bütünlük, dürüstlük ve etkisel tutumların bulunması,

- Geniş anlamda politik, sosyal, ekonomik, yerel ve kültürel bağlamdaki değişmeleri anlamak ve uyum sağlamak.

Temel girdisi ve çıktısı insan olan eğitim kurumlarında insan ilişkilerinin ve bu ilişkilerin yönetimi büyük öneme sahiptir(Başaran, 2004:72). Okullarında değişim ve gelişmeyi başlatan yöneticiler, öğrenci ve öğretmen beklentilerini dikkate almanın yanında katılımcı yönetim uygulamaları ile her zaman önder olabilmelidir (Korkmaz, vd.,2015:246).Başarılı bir değişim için gerekli beceri istek ve bilgiyi analiz ederek, çevresini cesaretlendirmelidir( Beytekin,2004). Okul yöneticilerinin, öğretmenlerin performanslarını artırmak ve kurumun büyümesi yönünde çalışmalar yapmaları gerekmektedir. Öğretmenlerin performanslarının yüksek olması için de motivasyonlarını yüksek tutmak önemlidir. Motivasyon çalışanın performansını artırmakla birlikte kurumun ve yönetimin de verimliliğine, hedeflerine ulaşmasına pozitif yönlü katkı sağlamaktadır(Aydın, 2011:222). Büyümenin ön koşulu, sürdürülebilirliktir. Sürdürülebilir büyümenin ön koşulu ise kurumsallaşmaktan geçer.

Kurumsallaşma: kurumların faaliyet gösterdikleri çevreleri ile olan uyum sürecini ve bu kurumlarda zamanla oluşan ilerlemeyi vurgulamaktadır(Selznick, 1996:271). Kurumsallaşma, sürdürülebilir başarı için iyi yönetim sistemlerinin uygulanmasıdır. Tüzel kişiliğin gerçek kişi ve kişilikten ayrılıp, işlevsel olarak ön plana çıktığı, çağdaş iş ve işletmecilik anlayışıyla etkinliklerin yürütüldüğü bir düzen olarak da tanımlanmaktadır. Yani kurumsallaşma, bir sistemleşme ve kurallaşma sürecidir. Ancak, kurumsallaşmanın her şeyin kurallara bağlandığı bir sistem olarak görülmemesi gerekmektedir. Bu sistem içinde, sürekli iyileştirme anlayışıyla, ortak çabaların ve insan faktörünün ön plana çıkarılması da önem taşımaktadır (Beşkonaklı ve Solaroğlu, 2007:34).

Kurumsal örgütlere bakıldığında; bütün süreçler hazırdır, iş akış şemaları, kişilerin yetki ve sorumlulukları belirlidir. Kişiler, bu iş akış şemalarına ve görev tanımlarına göre görevlerini yerine getirmede gerekli donanıma sahiptir. Kurumun ilkeleri, değerleri ve etik kuralları vardır. Bu ilke ve değerler, etik kurallar herkes tarafından benimsenir ve uygulanır. Yönetim ve/veya kişilerin değişmesi ile birlikte, iş yapış şeklinin farklı olduğu gerekçesiyle, temel kurallar değiştirilemez, ancak geliştirilmesi için çalışılır (Hacıoğlu,2017).

Kurumsallaşma, liderlik ve çalışanların performansı, günümüzde kurumların başarısı açısından en önemli faktörlerin başında gelmektedir. Kurum başarısı açısından insan kaynağını verimli şekilde yönetmek, performans düzeylerini artırmayı gerektirmektedir. Eğitim kurumlarında da tüm ilgili taraflar yani paydaşlar için (yönetim, öğrenciler, veliler, vb.) memnuniyetin sağlanması; bireylere, kurumlara ve ekonomiye önemli faydalar sağlayabileceği düşünülmektedir. 


\section{Yöntem}

Bu çalışmanın amacı, özel eğitim kurumlarında, kurumsallaşma düzeyi ve liderlik tarzlarının öğretmenlerin performansına etkilerinin önemini ortaya koymaktır. Çalışmada, kurumsallaşma seviyesinin önemi, liderlik türlerinin neler olduğu ve bunların ne şekilde kurumların süreçlerini, performansını etkilediklerinin tespit edilmesi ve çözüm önerilerinin geliştirilmesi amaçlanmıştır.

Araştırma özel bir eğitim kurumunun İstanbul'daki tüm şubelerinde görev yapan toplam 133 öğretmen ve yöneticiye uygulanmıştır. Örneklem belirlenirken kolayda örnekleme metodu tercih edilmiştir.

Verilerin analizinde SPSS 15.0 programı kullanılmıştır. Öğretmenlerin cinsiyet, yaş, öğrenim durumu ve mesleki kıdemlerine ilişkin demografik bilgileri frekans ve yüzde analizi olarak sunulmuştur. Performans uygulamaları, liderlik yaklaşımları ve kurumsallaşma uygulamalarına ilişkin puanların normallik sınamasında Çarpıklık (Skewness) katsayısı kullanılmıştır. Sürekli bir değişkenden elde edilen puanların normal dağılım özelliğinde kullanılan çarpıklık katsayısının (Skewness) \pm 1 sınırları içinde kalması puanların normal dağılımdan önemli bir sapma göstermediği şeklinde yorumlanabilir. Puanların normal dağılım göstermediği durumlarda parametrik testlerin kullanılabilmesi için karekök, logaritmik veya ters (inverse) dönüşümlerin yapılarak normal dağılımın sağlanması gerekir (Büyüköztürk, 2011:40). Normallik sınamasında puanların normal dağılım göstermediği tespit edildiğinden logaritmik dönüşümler yapılarak $\mathrm{t}$ ve ANOVA testlerinde dönüştürülmüş puanlar kullanılmıştır. Cinsiyet, öğrenim durumu ve mesleki kıdeme göre karşılaştırmalarda bağımsız iki örneklem $t$ testi; yaş değişkenine göre karşılaştırmalarda tek yönlü varyans analizi (ANOVA) testinden yararlanılmıştır. Analizlerde anlamlılık düzeyi $0,05 \quad(p<0,05)$ olarak belirlenmiştir.

\section{Bulgular}

Araştırma kapsamında incelenen 133 öğretmenin \%37,6's1 (50) erkek, \%62,4'ü (83) kadındır. Öğretmenlerin \%12'si (16) 20-25 yaş, \%39,8'i (53) 26-30 yaş, \%36,1'i (48) 31-35 yaş, \%12'si (16) 35 yaş üzerindedir. Öğretmenlerin \%69,2'si (92) lisans, \%30,8'i (41) lisansüstü düzeyde öğrenim görmüştür. Öğretmenlerin \%72,2'sinin (96) toplam hizmet süresi 5 y1l ve daha az, \%27,8'inin (37) 5 yıldan fazladır.

Yöneticilerin performans uygulamalarına ilişkin öğretmen görüşlerine ait her bir ifadeye ilişkin aritmetik ortalama ve standart sapma değerleri Tablo 1'de ayrıntılı olarak verilmiştir. 
Tablo 1. Yöneticilerin Performans Uygulamalarına İlişkin Görüşlere Ait Betimsel İstatistikler

\begin{tabular}{lll}
\hline Performans Uygulamalarına İlişkin Öğretmen Görüşleri & $\overline{\mathbf{X}}$ & SS \\
\hline $\begin{array}{l}\text { 8. Yöneticilerimizin kişisel sıkıntılarını yansıtmaması çalışanların } \\
\text { hizmet verimliliğinin artmasına neden olur. }\end{array}$ & 4,38 & 0,88 \\
\hline $\begin{array}{l}\text { 9. Eğitim çalışmalarının sürekliliği çalışanların iş tatminin } \\
\text { artmasını ve kariyerlerinde yükselmesini olumlu yönde etkiler. }\end{array}$ & 4,34 & 0,93 \\
\hline $\begin{array}{l}\text { 7. Yöneticimizin tavırları ürün ve hizmet kalitesinin artmasına } \\
\text { destek olur. }\end{array}$ & 4,31 & 0,89 \\
\hline \begin{tabular}{l} 
1. Yöneticimizin tavırları çalışanların örgütsel bağlılığını artırır. \\
\hline $\begin{array}{l}\text { 10. Performans değerlendirme sonuçlarının iletilmesi ve } \\
\text { değerlendirilmesi çalışanların performansını etkiler. }\end{array}$
\end{tabular} & 4,30 & 1,07 \\
\hline $\begin{array}{l}\text { 11. İş yerinde sosyal aktivitelerinin sürekliliği çalışanların } \\
\text { motivasyonunu etkiler. }\end{array}$ & 4,26 & 0,95 \\
\hline $\begin{array}{l}\text { 6. Yöneticimizin tavırları çalışan kapasitesinin tam kullanımına } \\
\text { neden olur. }\end{array}$ & 4,24 & 0,96 \\
\hline 3. Yöneticimizin tavırları işgücü devri azlığına neden olur. & 4,14 & 0,98 \\
\hline $\begin{array}{l}\text { 2. Yöneticimizin tavırları çalışanların işe geç gelmemesini teşvik } \\
\text { eder. }\end{array}$ & 4,09 & 1,11 \\
\hline $\begin{array}{l}\text { 12. Çalışanların kendi başına karar vermelerinin, iş verimliliği } \\
\text { üzerinde olumlu etkisi vardır. }\end{array}$ & 4,04 & 0,98 \\
\hline $\begin{array}{l}\text { 4. Yöneticimizin tavırları çalışanların duygusal bağlılığa neden } \\
\text { olur. }\end{array}$ & 4,02 & 1,08 \\
\hline 5. Yöneticimizin tavırları çalışanların ego tatminini artırır. & 3,86 & 1,19 \\
\hline
\end{tabular}

Öğretmen görüşlerine göre en önemli performans uygulamaları sırasıyla

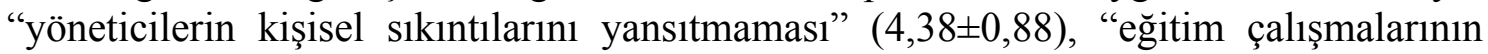
sürekliliğinin iş tatmini ve kariyer yükselmesine olumlu etkisi" $(4,34 \pm 0,93)$, "yönetici tavırlarının ürün ve hizmet kalitesinin artmasına destek olması" (4,31 $\pm 0,89)$, "yönetici tavırlarının örgütsel bağlılığı artırması" $(4,30 \pm 1,07)$ ve "performans değerlendirme sonuçlarının iletilmesi ve değerlendirilmesinin çalışanların performansını etkilemesi" $(4,29 \pm 0,95)$ olarak tespit edilmiştir. Öğretmenlere göre en az öneme sahip performans

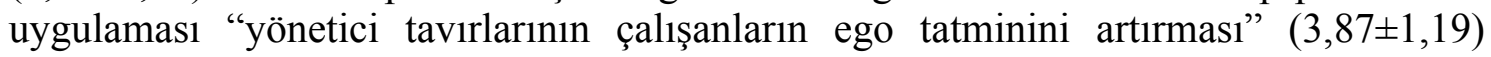
olarak tespit edilmiştir. Performans uygulamalarına ilişkin "yöneticilerin kişisel sıkıntılarını yansıtmaması", "yönetici tavırlarının ürün ve hizmet kalitesini artmasına destek olması", "yönetici tavırlarının ürün ve hizmet kalitesini artmasına destek olması", "yönetici tavırlarının örgütsel bağlılığı artırması", "performans değerlendirme sonuçlarının iletilmesi ve değerlendirilmesinin çalışanların performansını etkilemesi", "iş yerinde sosyal aktivitelerinin sürekliliğinin motivasyonu etkilemesi", "yönetici tavırlarının çalışan kapasitesinin tam kullanımına neden olması" görüşlerine ait puan ortalamaları "tamamen katılıyorum" düzeyinde; diğer görüşlere ait puan ortalamaları "kat1lıyorum" düzeyindedir.

Yöneticilerin performans uygulamalarına ilişkin öğretmen görüşlerine ait puanların demografik değişkenlere göre karşılaştırılması Tablo 2 ve Tablo 3'de ayrıntılı olarak verilmiştir. 
Tablo 2. Yöneticilerin Performans Uygulamalarına İlişsin Öğretmen Görüşlerinin Cinsiyete Göre Karşılaştırılmasına Ait T Testi Sonuçları

\begin{tabular}{lllllll}
\hline Görüşler & Cinsiyet N & $\overline{\mathbf{X}}$ & $\mathbf{S S}$ & $\mathbf{T}$ & $\mathbf{P}$ \\
\hline 1. Yöneticimizin tavırları çalışanların örgütsel & Erkek & 50 & 4,36 & 0,69 & $-0,45$ & 0,652 \\
bağlılığını artırır. & Kadın & 83 & 4,27 & 1,24 & & \\
\hline 2. Yöneticimizin tavırları çalışanların işe geç & Erkek & 50 & 4,26 & 0,83 & 0,91 & 0,367 \\
gelmemesini teşvik eder. & Kadın & 83 & 3,99 & 1,24 & & \\
\hline 3. Yöneticimizin tavırları işgücü devri azlığına & Erkek & 50 & 4,16 & 0,79 & $-0,45$ & 0,654 \\
neden olur. & Kadın & 83 & 4,12 & 1,09 & & \\
\hline 4. Yöneticimizin tavırları çalışanların duygusal & Erkek & 50 & 4,02 & 0,98 & $-0,34$ & 0,731 \\
bağlılığa neden olur. & Kadın & 83 & 4,02 & 1,15 & & \\
\hline 5. Yöneticimizin tavırları çalışanların ego & Erkek & 50 & 3,86 & 1,11 & $-0,04$ & 0,972 \\
tatminini artırır. & Kadın & 83 & 3,87 & 1,24 & & \\
\hline 6. Yöneticimizin tavırları çalışan kapasitesinin & Erkek & 50 & 4,20 & 0,73 & $-1,23$ & 0,221 \\
tam kullanımına neden olur. & Kadın & 83 & 4,27 & 1,08 & & \\
\hline 7. Yöneticimizin tavırları ürün ve hizmet & Erkek & 50 & 4,32 & 0,77 & $-0,30$ & 0,766 \\
kalitesinin artmasına destek olur. & Kadın & 83 & 4,30 & 0,96 & & \\
\hline 8. Yöneticilerimizin kişisel sıkıntılarını & Erkek & 50 & 4,22 & 0,79 & $-2,29$ & $\mathbf{0 , 0 2 4}$ \\
yansıtmaması çalışanların hizmet & Kadın & 83 & 4,47 & 0,93 & & \\
verimliliğinin artmasına neden olur. & & & & & & \\
\hline 9. Eğitim çalışmalarının sürekliliği çalışanlarınn & Erkek & 50 & 4,20 & 0,93 & $-1,66$ & 0,100 \\
iş tatminin artmasını ve kariyerlerinde & Kadın & 83 & 4,42 & 0,93 & & \\
yükselmesini olumlu etkiler. & & & & & & \\
\hline 10. Performans değerlendirme sonuçlarının & Erkek & 50 & 4,16 & 0,89 & $-1,64$ & 0,104 \\
iletilmesi ve değerlendirilmesi çalışanların & Kadın & 83 & 4,37 & 0,98 & & \\
performansını etkiler. & & & & & & \\
\hline 11. İş yerinde sosyal aktivitelerinin sürekliliği & Erkek & 50 & 4,28 & 0,86 & $-0,10$ & 0,924 \\
çalışanların motivasyonunu etkiler. & Kadın & 83 & 4,24 & 1,01 & & \\
\hline 12. Çalışanların kendi başına karar & Erkek & 50 & 3,92 & 0,88 & $-1,70$ & 0,092 \\
vermelerinin, iş verimliliği üzerinde olumlu & Kadın & 83 & 4,11 & 1,04 & & \\
etkisi vardır. & & & & & & \\
\hline
\end{tabular}

Yöneticilerin performans uygulamalarına ilişkin görüşlerinden "yöneticilerin kişisel sıkıntılarını yansıtmaması çalışanların hizmet verimliliğinin artmasına neden olur" görüşüne ait puanların cinsiyete göre anlamlı farklılık gösterdiği tespit edilmiştir $(\mathrm{t}=-2,29 ; \quad \mathrm{p}<0,05) . \quad$ Kadın öğretmenlerin yöneticilerin kişisel sıkıntılarını yansıtmamasının çalışanların hizmet verimliliğinin artmasına neden olduğuna ilişkin görüşlerine ait puan ortalaması $(4,47 \pm 0,79)$, erkek öğretmenlerin puanlarından $(4,22 \pm 0,79)$ anlamlı düzeyde daha yüksektir. Yöneticilerin performans uygulamalarına ilişkin diğer görüşlere ait puanların cinsiyete göre anlamlı farklılık göstermediği tespit edilmiştir (Tablo 2). 
Tablo 3. Yöneticilerin Performans Uygulamalarına İlişkin Görüşlerin Yaş Gruplarına Göre Karşılaştırılmasına Ait ANOVA Testi Sonuçları

\begin{tabular}{|c|c|c|c|c|c|}
\hline Görüsler & Yas & $\mathbf{N} \overline{\mathbf{X}}$ & SS & $\mathbf{F}$ & $\begin{array}{l}\text { Anlamlı } \\
\text { Fark }\end{array}$ \\
\hline \multirow{4}{*}{$\begin{array}{l}\text { 1. Yöneticimizin tavırları } \\
\text { çalışanların örgütsel bağlılığını } \\
\text { artırır. }\end{array}$} & 20-25 yaș & 164,13 & 1,20 & 0,65 & \multirow[t]{4}{*}{0,582} \\
\hline & $26-30$ yaş & 534,19 & 1,26 & & \\
\hline & $31-35$ yaş & 484,42 & 0,74 & & \\
\hline & 35 yaş üzeri & 164,50 & 1,10 & & \\
\hline \multirow{4}{*}{$\begin{array}{l}\text { 2. Yöneticimizin tavırları } \\
\text { çalışanların işe geç gelmemesini } \\
\text { teşvik eder. }\end{array}$} & A-20-25 yaş & 164,00 & 1,15 & 3,07 & \multirow[t]{4}{*}{$\mathbf{0 , 0 3 0} \mathrm{D}>\mathrm{A}, \mathrm{B}, \mathrm{C}$} \\
\hline & B-26-30 yaş & 533,85 & 1,28 & & \\
\hline & $\mathrm{C}-31-35$ yaş & 484,17 & 0,97 & & \\
\hline & $\begin{array}{l}\text { D-35 yaş } \\
\text { üzeri }\end{array}$ & 164,75 & 0,45 & & \\
\hline \multirow{4}{*}{$\begin{array}{l}\text { 3. Yöneticimizin tavırları işgücü } \\
\text { devri azlığına neden olur. }\end{array}$} & $20-25$ yaş & 164,31 & 0,87 & 1,08 & \multirow[t]{4}{*}{0,358} \\
\hline & $26-30$ yaş & 534,21 & 1,01 & & \\
\hline & $31-35$ yaş & 483,98 & 0,93 & & \\
\hline & 35 yaş üzeri & 164,19 & 1,17 & & \\
\hline \multirow{4}{*}{$\begin{array}{l}\text { 4. Yöneticimizin tavırları } \\
\text { çalışanların duygusal bağlılığa } \\
\text { neden olur. }\end{array}$} & $20-25$ yaş & 164,19 & 0,83 & 0,13 & \multirow[t]{4}{*}{0,942} \\
\hline & 26-30 yaş & 533,92 & 1,22 & & \\
\hline & $31-35$ yaş & 484,08 & 0,87 & & \\
\hline & 35 yaş üzeri & 164,00 & 1,41 & & \\
\hline \multirow{4}{*}{$\begin{array}{l}\text { 5. Yöneticimizin tavırları } \\
\text { çalışanların ego tatminini artırır. }\end{array}$} & $20-25$ yaş & 163,88 & 1,36 & 0,34 & \multirow[t]{4}{*}{0,794} \\
\hline & $26-30$ yaş & 533,96 & 1,02 & & \\
\hline & 31-35 yaş & 483,73 & 1,25 & & \\
\hline & 35 yaș üzeri & 163,94 & 1,39 & & \\
\hline \multirow{4}{*}{$\begin{array}{l}\text { 6. Yöneticimizin tavırları çalışan } \\
\text { kapasitesinin tam kullanımına } \\
\text { neden olur. }\end{array}$} & $20-25$ yaş & 164,06 & 1,44 & 0,13 & \multirow[t]{4}{*}{0,944} \\
\hline & $26-30$ yaş & 534,19 & 1,00 & & \\
\hline & 31-35 yaş & 484,33 & 0,81 & & \\
\hline & 35 yaş üzeri & 164,31 & 0,70 & & \\
\hline \multirow{4}{*}{$\begin{array}{l}\text { 7. Yöneticimizin tavırları ürün } \\
\text { ve hizmet kalitesinin artmasına } \\
\text { destek olur. }\end{array}$} & $20-25$ yaş & 164,44 & 0,73 & 0,12 & \multirow[t]{4}{*}{0,945} \\
\hline & $26-30$ yaş & 534,23 & 1,05 & & \\
\hline & $31-35$ yaş & 484,35 & 0,76 & & \\
\hline & 35 yaş üzeri & 164,31 & 0,87 & & \\
\hline \multirow{4}{*}{$\begin{array}{l}\text { 8. Yöneticilerimizin kişisel } \\
\text { sıkıntılarını yansıtmaması } \\
\text { çalışanların hizmet } \\
\text { verimliliğinin artmasına neden } \\
\text { olur }\end{array}$} & $20-25$ yaş & 164,38 & 1,09 & 0,04 & \multirow[t]{4}{*}{0,990} \\
\hline & $26-30$ yaş & 534,40 & 0,84 & & \\
\hline & $31-35$ yaş & 484,38 & 0,87 & & \\
\hline & 35 yaş üzeri & 164,31 & 0,95 & & \\
\hline \multirow{4}{*}{$\begin{array}{l}\text { 9. Eğitim çalışmalarının } \\
\text { sürekliliği çalışanların iş } \\
\text { tatminin artmasını ve } \\
\text { kariyerlerinde yükselmesini } \\
\text { olumlu yönde etkiler. }\end{array}$} & 20-25 yaş & 164,75 & 0,45 & 2,22 & \multirow[t]{4}{*}{0,088} \\
\hline & $26-30$ yaş & 534,15 & 1,08 & & \\
\hline & $31-35$ yaş & 484,48 & 0,74 & & \\
\hline & 35 yaş üzeri & 164,13 & 1,09 & & \\
\hline \multirow{3}{*}{$\begin{array}{l}\text { 10. Performans değerlendirme } \\
\text { sonuçlarının iletilmesi ve } \\
\text { değerlendirilmesi çalışanların }\end{array}$} & 20-25 yaş & 164,19 & 1,05 & 0,73 & \multirow[t]{3}{*}{0,535} \\
\hline & $26-30$ yaş & 534,15 & 1,12 & & \\
\hline & $31-35$ yaş & 484,42 & 0,77 & & \\
\hline
\end{tabular}




\begin{tabular}{|c|c|c|c|c|c|}
\hline performansını etkiler. & 35 yaş üzeri & 164,50 & 0,73 & & \\
\hline 11. İş yerinde sosyal & $20-25$ yaş & 164,19 & 0,91 & \multirow{4}{*}{\multicolumn{2}{|c|}{$1,95 \quad 0,125$}} \\
\hline aktivitelerinin sürekliliği & $26-30$ yaş & 534,08 & 1,09 & & \\
\hline çalışanların motivasyonunu & $31-35$ yaş & 484,52 & 0,68 & & \\
\hline etkiler & 35 yaş üzeri & 164,13 & 1,09 & & \\
\hline 12. Çalışanların kendi başına & $20-25$ yaş & 164,31 & 0,70 & \multirow[t]{4}{*}{0,85} & \multirow[t]{4}{*}{0,470} \\
\hline karar vermelerinin, iş verimliliği & $26-30$ yaş & 533,85 & 1,17 & & \\
\hline üzerinde olumlu etkisi vardır & $31-35$ yaş & 484,19 & 0,73 & & \\
\hline & 35 yaş üzeri & 163,94 & 1,12 & & \\
\hline
\end{tabular}

Yöneticilerin performans uygulamalarına ilişkin görüşlerinden "yöneticilerin tavırları çalışanların işe geç gelmemesini teşvik eder" görüşüne ait puanların yaş gruplarına göre anlamlı farklılık gösterdiği tespit edildi $(F=3,07 ; p<0,05)$. Farkın hangi gruplar arasında olduğunu belirlemek amacıyla yapılan LSD post hoc testi sonuçlarına göre 35 yaş üzeri öğretmenlerin yöneticilerin tavırlarının çalışanların işe geç gelmemesini teşvik ettiğine ilişkin görüşlerine ait puan ortalaması $(4,75 \pm 0,45), 20-25$ yaş $(4,00 \pm 1,15), 26-30$ yaş $(3,85 \pm 1,28)$ ve $31-35$ yaş $(4,17 \pm 0,97)$ grubu öğretmenlerin puanlarından anlamlı düzeyde daha yüksektir. Yöneticilerin performans uygulamalarına ilişkin diğer görüşlere ait puanların yaş gruplarına göre anlamlı farklılık göstermediği tespit edilmiştir (Tablo 3).

Yöneticilerin performans uygulamalarına ilişkin öğretmen görüşlerine ait puanların öğrenim durumuna göre anlamlı farklılık göstermediği tespit edilmiştir.

Yöneticilerin performans uygulamalarına ilişkin öğretmen görüşlerine ait puanların mesleki kıdeme göre anlamlı farklılık göstermediği tespit edilmiştir.

Yöneticilerin liderlik yaklaşımlarına ilişkin öğretmen görüşlerine ait her bir ifadeye ilişkin aritmetik ortalama ve standart sapma değerleri Tablo 4'de ayrıntılı olarak verilmiştir.

Tablo 4. Yöneticilerin Liderlik Yaklaşımlarına İlişkin Öğretmen Görüşlerine Ait Betimsel İstatistikler

\begin{tabular}{lcc}
\hline Yöneticilerin Liderlik Yaklaşımına İlişkin Öğretmen Görüşleri & $\overline{\mathbf{X}}$ & $\mathbf{S S}$ \\
\hline $\begin{array}{l}\text { 10. Kurum yöneticilerimizin çalışanlarla iyi iletişimi, yönetimde } \\
\text { etkinliği sağlar. }\end{array}$ & 4,49 & 0,87 \\
\hline $\begin{array}{l}\text { 11. Kurum yöneticilerimizin çalışanların kararlarına önem } \\
\text { vermeleri, çalışanların örgüt bağl1lığını olumlu yönde etkiler. }\end{array}$ & 4,44 & 0,92 \\
\hline $\begin{array}{l}\text { 12. Yöneticilerimizin yeteneklerine göre çalışanları ödüllendirmesi } \\
\text { motivasyonumuzu artırır. }\end{array}$ & 4,44 & 0,89 \\
\hline $\begin{array}{l}\text { 3. Kurum yöneticilerimizin öğretimsel liderlik (çalışanlarının } \\
\text { yeteneklerini geliştiren, eğitimi önemseyen) yaklaşımı, yönetimde } \\
\text { etkinliği sağlar. }\end{array}$ & 4,32 & 0,98 \\
\hline $\begin{array}{l}\text { 7. Kurum yöneticilerimizin karizmatik liderlik (çalışanların } \\
\text { ihtiyaçlarını anlayan, vizyon oluşturan, kendine güveni yüksek } \\
\text { olan) yaklaşımı, yönetimde etkinliği sağlar. }\end{array}$ & 4,31 \\
\hline $\begin{array}{l}\text { 4. Kurum yöneticilerimizin kolaylaştırıcı liderlik (çalışanlarının, } \\
\text { mesai saatleri, inisiyatif kullanmalarını vs. esnekleştirme) }\end{array}$ & 0,96 \\
$\begin{array}{l}\text { yaklaşımı, yönetimde etkinliği sağlar. } \\
\text { 5. Kurum yöneticilerimizin etik liderlik (etik değerleri önceleme, }\end{array}$ & $0,9,29$ \\
\hline
\end{tabular}




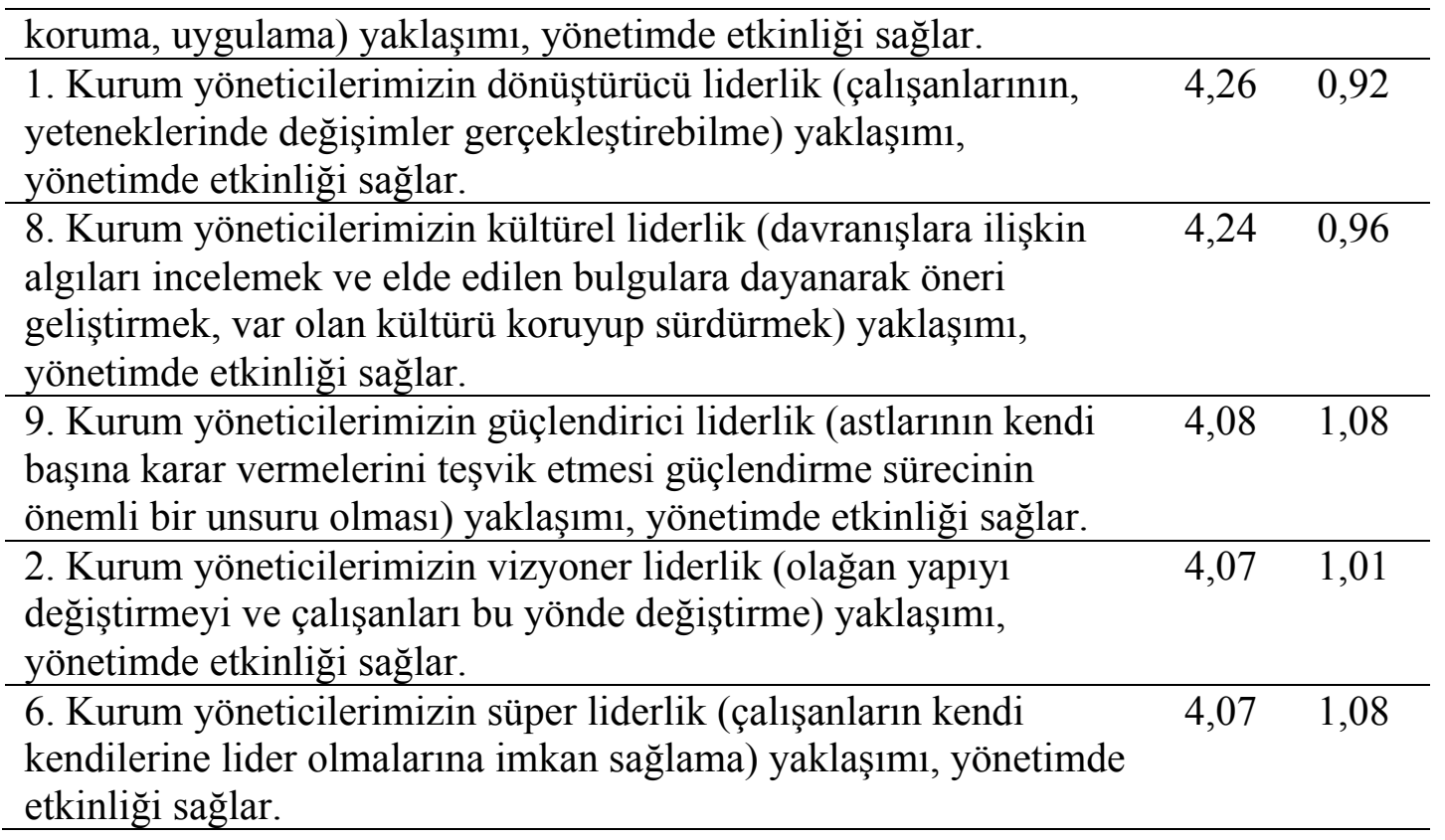

Öğretmen görüşlerine göre en önemli liderlik yaklaşımları sırasıyla "çalışanlarla iyi iletişimin yönetimde etkinlik sağlaması" $(4,49 \pm 0,87)$, "çalışanların kararlarına önem

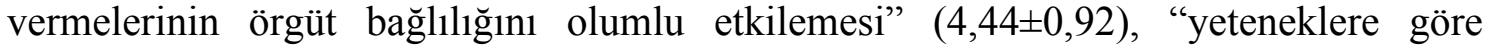
ödüllendirmenin motivasyonu artırması" $(4,44 \pm 0,89)$, "öğretimsel liderlik yaklaşımının yönetimde etkinliği sağlaması" $(4,32 \pm 0,98)$ ve "karizmatik liderlik yaklaşımının yönetimde etkinliği sağlaması" $(4,31 \pm 0,96)$ olarak tespit edilmiştir. Öğretmenlere göre en az öneme sahip liderlik yaklaşımları "süper liderlik" $(4,07 \pm 1,08)$, "vizyoner liderlik" $(4,07 \pm 1,01)$ ve "güçlendirici liderlik" $(4,08 \pm 1,08)$ olarak tespit edilmiştir. Liderlik yaklaşımlarına ilişkin "süper liderlik", "vizyoner liderlik" ve "güçlendirici liderlik" yaklaşımlarına ilişkin görüşlere ait puan ortalamaları "katılıyorum" düzeyinde; diğer liderlik yaklaşımlarına ilişkin görüşlere ait puan ortalamaları "tamamen katılıyorum" düzeyindedir (Tablo 4).

Yöneticilerin liderlik yaklaşımlarına ilişkin öğretmen görüşlerine ait puanların demografik değişkenlere göre karşılaştırılmasına aşağıda ayrıntılı olarak verilmiştir.

Tablo 5. Yöneticilerin Liderlik Yaklaşımlarına İlişkin Görüşlerin Cinsiyete Göre Karşılaştırılmasına Ait T Testi Sonuçları

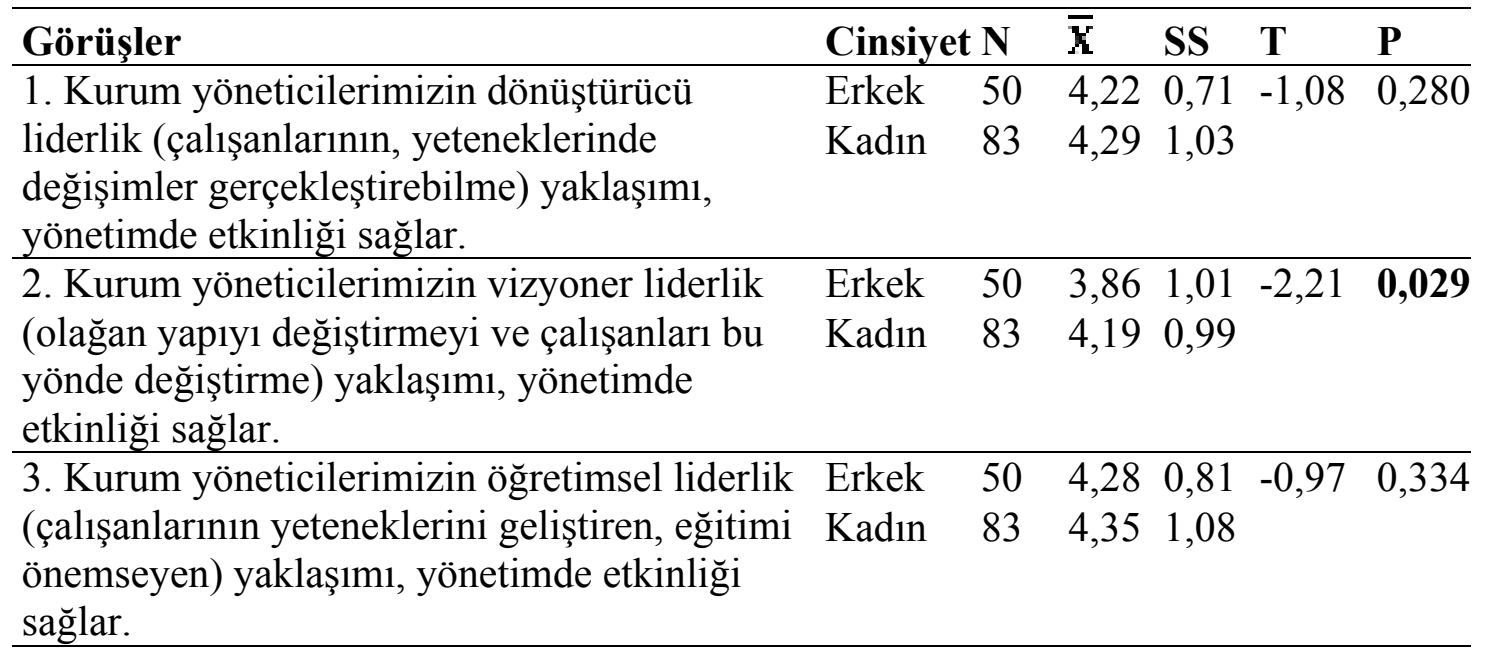




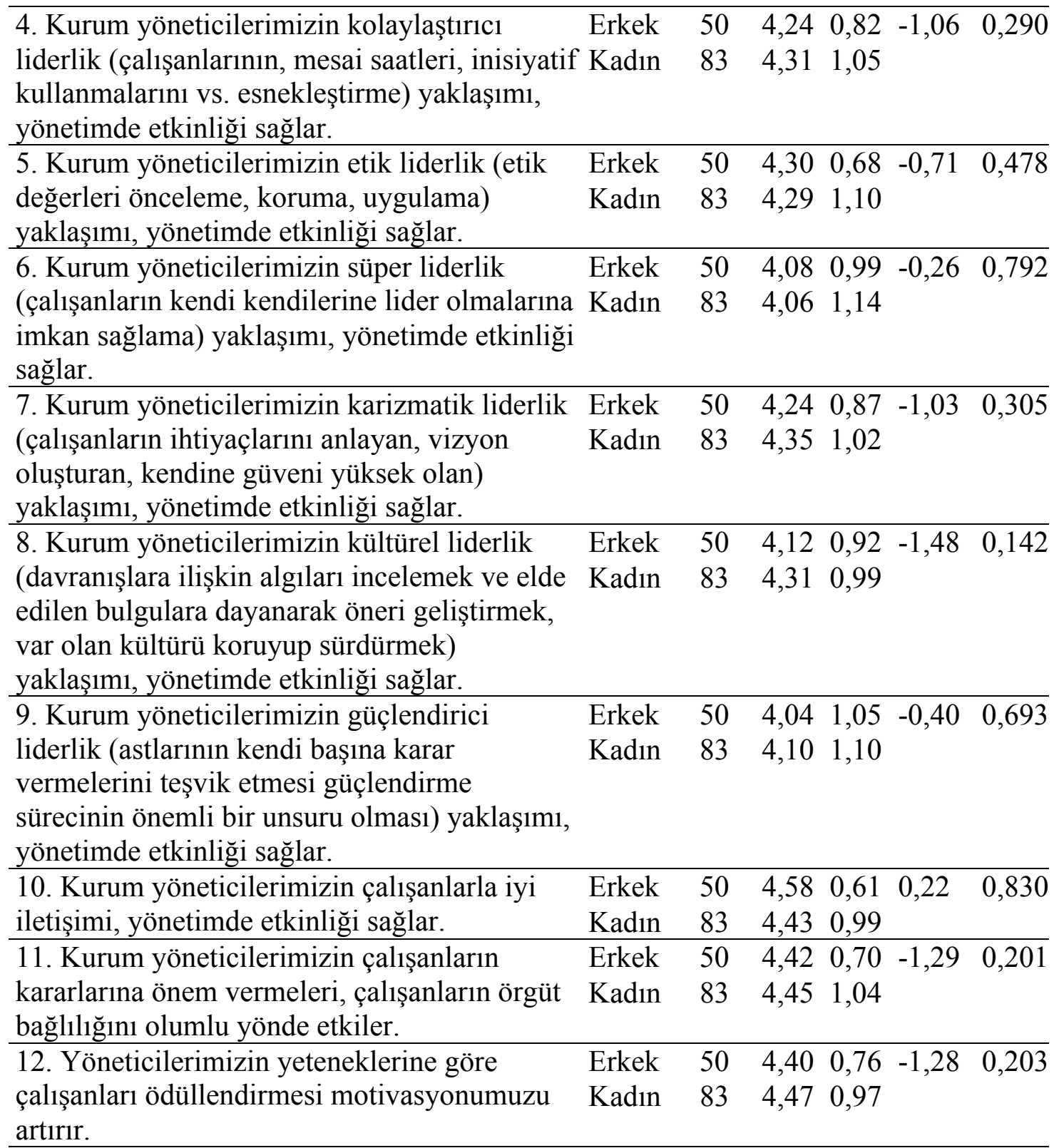

Yöneticilerin liderlik yaklaşımlarına ilişkin görüşlerinden "vizyoner liderlik yaklaşımının yönetimde etkinliği sağladığı" görüşüne ait puanların cinsiyete göre anlamlı farklılık gösterdiği tespit edilmiştir $(\mathrm{t}=-2,21 ; \mathrm{p}<0,05)$. Kadın öğretmenlerin yöneticilerin vizyoner liderlik yaklaşımının yönetimde etkinliği sağladığına ilişkin görüsslerine ait puan ortalaması $(4,19 \pm 0,99)$, erkek öğretmenlerin puanlarından $(3,86 \pm 1,01)$ anlamlı düzeyde daha yüksektir. Yöneticilerin liderlik yaklaşımlarına ilişkin diğer görüşlere ait puanların cinsiyete göre anlamlı farklılık göstermediği tespit edilmiştir (Tablo 5).

Yöneticilerin liderlik yaklaşımlarına ilişkin öğretmen görüşlerinin yaş gruplarına göre karşılaştırılmasına ait Anova testi sonuçlarına göre, puanların yaş gruplarına göre anlamlı farklılık göstermediği tespit edilmiştir. 
Yöneticilerin liderlik yaklaşımlarına ilişkin öğretmen görüşlerinin öğrenim durumuna göre karşılaştırılmasına ait $T$ testi sonuçlarına göre, öğrenim durumuna göre anlamlı farklılık göstermediği tespit edilmiştir.

Yöneticilerin liderlik yaklaşımlarına ilişkin öğretmen görüşlerine ait $\mathrm{T}$ testi sonuçlarına göre, puanların mesleki kıdeme göre anlamlı farklılık göstermediği tespit edilmiştir.

Kurumsallaşma uygulamalarına ilişkin öğretmen görüşlerine ait her bir ifadeye ilişkin aritmetik ortalama ve standart sapma değerleri Tablo 6'da ayrıntılı olarak verilmiştir.

\section{Tablo 6. Kurumsallaşma Uygulamalarına İlişsin Öğretmen Görüşlerine Ait} Betimsel İstatistikler

\begin{tabular}{lll}
\hline Kurumsallaşma Uygulamalarına İlişkin Öğretmen Görüşleri & $\overline{\mathbf{X}}$ & $\mathbf{S S}$ \\
\hline $\begin{array}{l}\text { 7. Kurumun kurumsallaşması ile ilgili çalışmalarda, çalışanların } \\
\text { önerileri ve taleplerinin dikkate alınması, işletmenin verimliliğini } \\
\text { olumlu yönde etkiler. }\end{array}$ & 4,35 & 0,90 \\
\hline $\begin{array}{l}\text { 3. Yönetimin temel görevi değişim konusunda çalışanlara önderlik } \\
\text { etmesidir. }\end{array}$ & 4,24 & 0,99 \\
\hline $\begin{array}{l}\text { 4. Örgütlerin başarısı, yönetici ve çalışanların kurumsallaşma } \\
\text { konusunda güç birliği ile faaliyetleri sürdürmelerine bağldır. }\end{array}$ & 4,21 & 1,04 \\
\hline $\begin{array}{l}\text { 5. Çalışanların statüsüne bakılmadan karar süreçlerine çalışanları } \\
\text { dahil etmelidir. }\end{array}$ & 4,14 & 1,02 \\
\hline $\begin{array}{l}\text { 1. Kurumsallaşma çalışmalarının ilk aşamasını; kurumsal vizyon- } \\
\text { misyonun tanımlanması ve çalışanlarla birlikte kurumsal felsefe, } \\
\text { inanç, değer, ilke ve normların paylaşılması oluşturmaktadır. }\end{array}$ & 4,12 & 1,00 \\
\hline $\begin{array}{l}\text { 8. Yöneticiler, çalışanların iş yerindeki sorunlarının yanı sira iş yeri } \\
\text { dişındaki sorunlarıyla ilgilenmeleri çalışanların verimliliğini } \\
\text { olumlu yönde etkiler. }\end{array}$ & 4,08 \\
\hline $\begin{array}{l}\text { 2. Kurumsal imaj, kurumsal iletişim ve kurumsal kimlik oluşturma } \\
\text { oluşumları; kurumsallaşma sürecinin temel çerçevesini } \\
\text { oluştururken, aynı zamanda entelektüel sermayenin de } \\
\text { geliştirilmesini ve etkinleştirilmesini sağlar. }\end{array}$ & 4,05 \\
\hline
\end{tabular}

$\begin{array}{lll}\text { 6. Bir problem olduğunda kurumsal kurallar dışına çıkılmamalıdır. } \quad 3,65 & 1,23\end{array}$

Öğretmen görüşlerine göre en önemli kurumsallaşma uygulamaları sırasıyla "çalışanların öneri ve taleplerinin dikkate alınmasının verimliliği olumlu yönde etkilemesi" (4,35 $\pm 0,90)$, "yönetimin temel görevinin değişim konusunda çalışanlara önderlik etmesi" $(4,24 \pm 0,99)$ ve "örgütlerin başarısının yönetici ve çalışanların kurumsallaşma konusunda güç birliği ile faaliyetleri sürdürmesine bağli olduğu" $(4,21 \pm 1,04)$ olarak tespit edilmiştir. Öğretmenlere göre en az öneme sahip kurumsallaşma uygulamaları "bir problem olduğunda kurumsal kurallar dışına çıkılmaması" (3,65 $\pm 1,23)$ olarak tespit edilmiştir. Kurumsallaşma uygulamalarına ilişkin "çalışanların öneri ve taleplerinin dikkate alınmasının verimliliği olumlu yönde etkilemesi" ve "yönetimin temel görevinin değişim konusunda çalışanlara önderlik etmesi" uygulamalarına ilişkin görüşlere ait puan ortalamaları "tamamen katılıyorum" düzeyinde; diğer kurumsallaşma uygulamalarına ilişkin görüşlere ait puan ortalamaları "kat1lıyorum" düzeyindedir (Tablo 6). 
Kurumsallaşma uygulamalarına ilişkin görüşlerin cinsiyete göre karşılaştırılmasına ait $\quad T$ testi sonuçlarına göre, öğretmen görüşlerine ait puanların cinsiyete göre anlamlı farklılık göstermediği tespit edilmiştir.

Kurumsallaşma uygulamalarına ilişkin öğretmen görüşlerine ait puanların yaş gruplarına göre karşılaştırılmasına ait Anova testi sonuçları, anlamlı farklılık göstermediği tespit edilmiştir.

\section{Tablo 7. Kurumsallaşma Uygulamalarına İlişkin Görüşlerin Öğrenim Durumuna Göre Karşılaştırılmasına Ait T Testi Sonuçları}

\begin{tabular}{|c|c|c|}
\hline Görüşler & $\begin{array}{l}\text { Öğrenim } \\
\text { Durumu } N \bar{X}\end{array}$ & SS \\
\hline $\begin{array}{l}\text { 1. Kurumsallaşma çalışmalarının ilk aşamasını; } \\
\text { kurumsal vizyon-misyonun tanımlanması ve } \\
\text { çalışanlarla birlikte kurumsal felsefe, inanç, değer, } \\
\text { ilke ve normların paylaşılması oluşturmaktadır. }\end{array}$ & 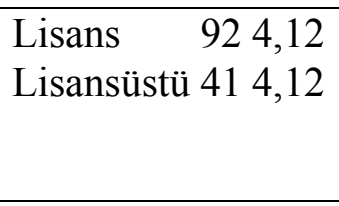 & $\begin{array}{l}0,99-0,180,857 \\
1,03\end{array}$ \\
\hline $\begin{array}{l}\text { 2. Kurumsal imaj, kurumsal iletişim ve kurumsal } \\
\text { kimlik oluşturma oluşumları; kurumsallaşma } \\
\text { sürecinin temel çerçevesini oluştururken, aynı } \\
\text { zamanda entelektüel sermayenin de geliştirilmesini } \\
\text { ve etkinleştirilmesini sağlar. }\end{array}$ & $\begin{array}{lrl}\text { Lisans } & 92 & 4,03 \\
\text { Lisansüstü } & 41 & 4,10\end{array}$ & $\begin{array}{l}0,99-0,080,938 \\
0,83\end{array}$ \\
\hline $\begin{array}{l}\text { 3. Yönetimin temel görevi değişim konusunda } \\
\text { çalişanlara önderlik etmesidir. }\end{array}$ & 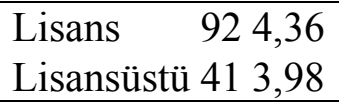 & $\begin{array}{l}0,922,12 \quad \mathbf{0 , 0 3 6} \\
1,11\end{array}$ \\
\hline $\begin{array}{l}\text { 4. Örgütlerin başarısı, yönetici ve çalışanların } \\
\text { kurumsallaşma konusunda güç birliği ile faaliyetleri } \\
\text { sürdürmelerine bağlıdır. }\end{array}$ & $\begin{array}{lrl}\text { Lisans } & 92 & 4,21 \\
\text { Lisansüstü } & 41 & 4,22 \\
\end{array}$ & 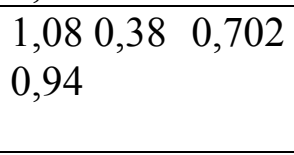 \\
\hline $\begin{array}{l}\text { 5. Çalışanların statüsüne bakılmadan karar } \\
\text { süreçlerine çalışanları dahil etmelidir. }\end{array}$ & 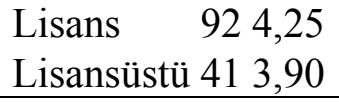 & $\begin{array}{l}0,94 \quad 1,77 \quad 0,079 \\
1,16\end{array}$ \\
\hline $\begin{array}{l}\text { 6. Bir problem olduğunda kurumsal kurallar dişına } \\
\text { çıkılmamalıdır. }\end{array}$ & 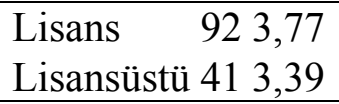 & $\begin{array}{l}1,181,660,099 \\
1,32\end{array}$ \\
\hline $\begin{array}{l}\text { 7. Kurumun kurumsallaşması ile ilgili çalışmalarda, } \\
\text { çalışanların önerileri ve taleplerinin dikkate } \\
\text { alınması, işletmenin verimliliğini olumlu yönde } \\
\text { etkiler. }\end{array}$ & $\begin{array}{lrl}\text { Lisans } & 92 & 4,33 \\
\text { Lisansüstü } & 41 & 4,39\end{array}$ & $\begin{array}{l}0,92-0,390,696 \\
0,89\end{array}$ \\
\hline $\begin{array}{l}\text { 8. Yöneticiler, çalışanların iş yerindeki sorunlarının } \\
\text { yanı sıra iş yeri dışındaki sorunlarıyla ilgilenmeleri } \\
\text { çalışanların verimliliğini olumlu yönde etkiler. }\end{array}$ & 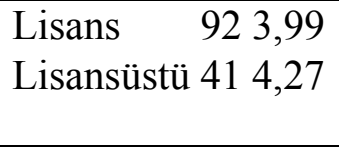 & $\begin{array}{l}1,15-1,180,240 \\
0,92\end{array}$ \\
\hline
\end{tabular}

Kurumsallaşma uygulamalarına ilişkin görüşlerden "yönetimin temel görevinin değişim konusunda çalışanlara önderlik etmesi olduğu” görüşüne ait puanların öğrenim durumuna göre anlamlı farklılık gösterdiği tespit edildi $(\mathrm{t}=2,12 ; \mathrm{p}<0,05)$. Lisans düzeyinde öğrenim gören öğretmenlerin yönetimin temel görevinin değişim konusunda çalışanlara önderlik etmesi olduğuna ilişkin görüşlerine ait puan ortalaması $(4,36 \pm 0,92)$, lisansüstü düzeyde öğrenim gören öğretmenlerin puanlarından $(3,98 \pm 1,11)$ anlamlı düzeyde daha yüksektir. Kurumsallaşma uygulamalarına ilişkin diğer görüşlere ait puanların öğrenim durumuna göre anlamlı farklılık göstermediği tespit edilmiştir.

Kurumsallaşma uygulamalarına ilişkin öğretmen görüşlerine ait puanların mesleki kıdeme göre karşılaştırılmasına ait $\mathrm{T}$ testi sonuçlarına göre, anlamlı farklılık göstermediği tespit edilmiştir. 
Yöneticilerin performans uygulamalarına ilişkin öğretmen görüşleri ile yöneticilerin liderlik yaklaşımlarına ilişkin öğretmen görüşleri arasında genel olarak pozitif yönde anlamlı ilişki bulunmaktadır. Yöneticilerin performans uygulamalarına ilişskin görüşlerine ait puanları yüksek olan öğretmenlerin yöneticilerin liderlik yaklaşımlarına ait puanları da yüksektir.

Kurumsallaşma uygulamalarına ilişkin öğretmen görüşleri ile yöneticilerin liderlik yaklaşımlarına dair öğretmen görüşleri arasında pozitif yönde anlamlı ilişki bulunmaktadır. Kurumsallaşma uygulamalarına ilişkin görüşlerine ait puanları yüksek olan öğretmenlerin, yöneticilerin liderlik yaklaşımlarına ait puanları da yüksektir.

\section{Sonuç ve Tartışma}

Eğitim sisteminde okul, önemli bir alt sistemdir ve okulların başarısı da eğitim sisteminin başarısı için gerekli en kritik değişkenlerin başında gelmektedir. Bu noktada, mikro düzeyde okul yöneticileri kilit faktördür. Okul yöneticisinin kararları, motivasyonu ve iş yapış biçimi tüm süreci etkilemektedir. Kurumda motivasyonun yüksek olması çalışanların performanslarını etkileyecek, bu durum da kurumun başarısını artırabilecektir.

Bu bağlamda, okul yöneticileri; başta insan kaynağı olmak üzere; okuldaki tüm kaynakları en etkin, etkili ve verimli şekilde kullanarak, okulu amaçlarına uygun bir şekilde yöneterek; okulun gelişmesi ve büyümesinde önemli bir yere sahiptirler. Kurumdaki öğrenme iklimini, profesyonellik düzeyini, öğretmen bağlılığını, öğrenci başarısını ve öğretmenlerin performanslarını etkileyen yönetimin liderliğidir. Bir okul, yeniliğe açıksa, öğrenci merkezliyse, öğretimde mükemmellik için çalışıyorsa, öğrenciler ve öğretmenler yeteneklerini en iyi şekilde sergileyebiliyorlarsa, yöneticilerin liderliğinin bu başarının önemli bir unsuru olarak gerekli olduğu söylenebilir. Eğitimde hedeflenen amaçlara ve başarıya ulaşabilmenin başat şartlarından birisi öğretmenlerin performansıdır. Okul yöneticilerinin, öğretmenlerin performanslarını artırmak ve kurumun büyümesi yönünde çalışmalar yapmaları gerekmektedir. Büyümenin ön koşulu, sürdürülebilirliktir. Sürdürülebilir büyümenin ön koşulu ise kurumsallaşmaktan geçer. $\mathrm{Bu}$ çalışma, bu noktadan hareketle öğretmen görüşlerinin çeşitli değişkenler açısından okul yöneticilerinin liderlik davranışları, performans uygulamaları ve kurumsallaşmaya ilişkin görüşlerini tespit etmeyi amaçlamıştır.

Ankete katılanların cinsiyetlerine bakıldığında kadın katılımcıların sayısının erkek katılımcılardan daha fazla olduğu saptanmıştır. Buna göre: anketin uygulandığ 133 kişinin 83'ü kadın 50'si erkektir. Eğitim kurumlarında kadın ve erkek eğitimci sayısının kurumun ihtiyaçları da dikkate alınarak belirlenmesi faydalı olabilir. Örneğin rehberlik danışmanlıkta yeterli sayıda erkek ve kadın öğretmenin ihtiyaçlara göre olmasının faydalı olacağ 1 düşünülmektedir.

Anketin uygulandığı kişiler, yaş bakımından incelendiğinde, en fazla öğretmenin 26-30 yaş arasında olduğu söylenebilir. En düşük yaş aralığını ise 20-25 yaş arası öğretmenler oluşturmaktadır. Özel kurumların belli bir deneyime sahip; genç ve dinamik çalışanların daha fazla tercih edildiği gözlemlenebilmektedir. Şanal'ın (2011) çalışmasında da belirttiği şekilde; kurumsallaşma ve kurumsal girişimcilik faaliyetlerinin amaçlarından birisi de yeniliklerin işletmeye hızlı bir şekilde uyarlanmasıdır. Gerek verimlilik artışı, gerekse yeniliklere uyum sağlama açısından 31- 
40 yaş arası grubun yoğunluğundan bahsedip tecrübe bakımından 20-25 yaş grubuna oranla daha tecrübeli bir grubu ele alsa da genç yaş grubunun yenilikçiliğe açık olma özelliğinin ve dinamik yapının işletmelerin avantajına olacağını ifade etmesi çalışmayı desteklemektedir.

Katılımcıların eğitim durumları incelendiğinde, en fazla lisans mezununun görev aldığg tespit edilmiştir Yaş kriteri bakımından, genç kesim, eğitim kurumlarında görevlendirildiğinden lisans mezunu çalışanların, yüksek lisans ve doktora programlarına yönlendirilmeleri eğitim kurumlarının eğitim-öğretim faaliyetlerinin kalitesini artırabileceği düşünülmektedir. Eğitim kurumları, eğitim seviyesi yüksek çalışanlardan meydana geldiği için yöneticilerin gösterdikleri liderlik davranışlarından başarı yönelimli liderlik, destekleyici ve katılımcı liderlik davranışları ön plana çıkmaktadır (Küçük, 2008: 88).

Öğretmen görüşlerine göre en önemli liderlik yaklaşımları sırasıyla "çalışanlarla iyi iletişimin yönetimde etkinlik sağlaması", "çalışanların kararlarına önem vermelerinin örgüt bağlılığını olumlu etkilemesi", "yeteneklere göre ödüllendirmenin motivasyonu artırması", "öğretimsel liderlik yaklaşımının yönetimde etkinliği sağlaması" ve "karizmatik liderlik yaklaşımının yönetimde etkinliği sağlaması" olarak tespit edilmiştir. Öğretmenlere göre en az öneme sahip liderlik yaklaşımları "süper liderlik", "vizyoner liderlik" ve "güçlendirici liderlik" olarak tespit edilmiştir.

Yöneticilerin liderlik yaklaşımlarına ilişkin görüşlerinden "vizyoner liderlik yaklaşımının yönetimde etkinliği sağladığı” görüşüne ait puanların cinsiyete göre anlamlı farklılık gösterdiği tespit edilmiştir. Kadın öğretmenlerin yöneticilerin vizyoner liderlik yaklaşımının yönetimde etkinliği sağladığına ilişkin görüşlerine ait puan ortalaması, erkek öğretmenlerin puanlarından anlamlı düzeyde daha yüksektir.

Öğretmen görüşlerine göre en önemli kurumsallaşma uygulamaları sırasıyla "çalışanların önerileri ve taleplerinin dikkate alınmasının, verimliliği olumlu yönde etkilemesi", "yönetimin temel görevinin değişim konusunda çalışanlara önderlik etmesi" ve "örgütlerin başarısının yönetici ve çalışanların kurumsallaşma konusunda güç birliği ile faaliyetleri sürdürmesine bağlı olduğu" olarak tespit edilmiştir. Öğretmenlere göre en az öneme sahip kurumsallaşma uygulamaları "bir problem olduğunda kurumsal kurallar dışına çıkılmaması" olarak tespit edilmiştir.

Kurumsallaşma uygulamalarına ilişkin görüşlerine ait puanları yüksek olan öğretmenlerin, yöneticilerin liderlik yaklaşımlarına ait puanları da yüksek olarak ölçülmüştür. Yöneticilerin performans uygulamalarına ilişkin görüşlerine ait puanları yüksek olan öğretmenlerin, yöneticilerin liderlik yaklaşımlarına ait puanlarının da yüksek olduğu tespit edilmiştir.

Kurumların hızla değişen ve gelişen dünya şartlarına uyum sağlayabilmeleri için, yönetim ile ilgili tüm karar ve uygulama süreçlerini, rekabet avantajı elde edecek, bireysel ve kurumsal performansı artıracak biçimde, yeni uygulamalar ve yöntemler geliştirerek güncellemeleri gerekmektedir. Söz konusu değişimin gerçekleştirilmesinde, en önemli farklılık kaynağ 1 ya da farklılık yaratabilecek unsuru insandır. Tüm iç ve dış paydaşların değerlendirilmesi ve yönetilmesi süreçlerini kapsayan Paydaş Yönetimi kavramı bireyin yönetimi açısından da çok önemli yer tutmaktadır. Kurumlarda çalışan bu birbirinden farklı personelin ihtiyaç ve istekleri göz önüne alınarak performans uygulamaları gerçekleştirilmelidir. Bu uygulamalar öğrenci, veli ve diğer grupların 
yönetilmesinde de dönüştürülerek, uyumlu bir biçimde yaşama geçirilmelidir. Öte yandan günümüz iş dünyası açısından, değişim ve yeniliğine ayak uydurabilmek için kurumsallaşma süreçlerinin de içselleştirilmesi gerekmektedir. Kurumsallaşma seviyesinin yüksek olduğu; etkin, etkili ve verimli yönetim ve liderlik süreçlerine sahip, çalışanların ve kurumun performanslarını artırıcı objektif uygulamaların gerçekleştirildiği, kurumsal yönetişim ilkelerini benimsemiş kurumların, sürdürülebilir büyüme ve gelişme açısından yadsınamaz bir güce sahip olabildikleri günümüz dünyasının en önemli değişkenleri olarak öne çıkmaktadır. Gerek mikro gerekse makro düzeyde, eğitim kurumları, tüm paydaşlarıyla birlikte eğitim sisteminin yönetimi; gelecek için en önemli değişkenlerin başında gelen birey için, hızlı değişim ve dönüşümün yaşandığı bu süreçte yaşamsal öneme sahiptir. $\mathrm{Bu}$ bağlamda eğitim kurumlarının yönetimi geleceğin ve değişimin yönetiminde doğrudan etkili olmaktadır.

\section{Kaynakça}

Apak, S., Bal, H., Şen, E. (2013), Kurumsal Yönetim İlkeleri Ve Finansal Yönetim, T.C. Kamu Gözetimi Muhasebe ve Denetim Standartları Kurumu ve T.C. Beykent Üniversitesi Yayımı, İstanbul.

Aydın, A. H.( 2011), Yönetim Bilimi, Seçkin Yayıncılık, Ankara.

Başaran, İ. E. (1996). Örgütsel Davranış: İnsanın Üretim Gücü, 2. Baskı, Gül Yayınevi, Ankara.

Başaran, İ. E.(2004). Yönetimde İnsan İlişkileri Yönetsel Davranış, 3.Baskı, Nobel Yayınevi, Ankara.

Beşkonakl1, E.,\&Solaroğlu, İ. (2007). Yolumuz Uzun! Değişim, Gelişim, Kurumsallaşma ve Kurumsal Kültür Üzerine, Türk Nöroşirurji Derneği Bülteni, 12(20.08), 2015.

Beytekin, O. F.( 2004). İlköğretim Okul Müdürleri İçin Eğitim Liderliği Standartlarının Araştırılması, Kocaeli Üniversitesi, Sosyal Bilimler Enstitüsü Yüksek Lisans Tezi, Kocaeli.

Bursalığlu, Z. (1998). Okul Yönetiminde Yeni Yapı ve Davranış. Pegem A Yayıncılık. Ankara.

Büyüköztürk, Ş.(2011), Sosyal Bilimler İçin Veri Analizi El Kitabı, 14. Baskı, Pegem Akademi, Ankara.

Carmeli, A.; Meiter, R. ve Weisberg, J. (2006a). Self-Leadership Skills and Innovative Behavior at Work. International Journal Of Manpower, 27(1). 75-90.

Carmeli, A. ve Tishler, A. (2006b). The Relative Importance of The Top Management Team's Managerial Skills. International Journal of Manpower, 27 (1). 9-36.

Çalık, T., \& Sezgin, F. (2005). Küreselleşme, Bilgi Toplumu ve Eğitim. Kastamonu Eğitim Dergisi, 13(1), 55-66.

Çelik, V. (2001). Geleceğin Okul Liderleri. 2000 Yılında Türk Millî Egitim Örgütü ve Yönetimi Ulusal Sempozyumu. Ankara: Başkent Öğretmen Evi. 
Doğan, E. (2002). Eğitimde Küreselleşme. Eğitim Araştırmaları Dergisi. Sayı: 6, Sayfa: $87-98$.

Erkuş, R.(1997). İlköğretim Okulları Müdürlerinin Liderlik Davranışları. Yayımlanmamış Bilim Uzmanlığı Tezi. Hacettepe Üniversitesi Sosyal Bilimler Enstitüsü: Ankara.

Hacıoğlu, H.(2017). Aile Şirketlerinde Kurumsallaşma. Erişim Tarihi:25 Temmuz 2017. http://www.hulyahacioglu.com.tr/aile-sirketlerinde-kurumsallasma-703.

Kılıncarslan, S. (2013). Okul Yöneticilerinin Liderlik Stilleri İle Öğretmenlerin Örgütsel Bağlılık Düzeyleri Arasındaki İlişkinin İncelenmesi (İzmir İli Karabağlar İlçesi Örneği). Okan Üniversitesi Sosyal Bilimler Enstitüsü, Yüksek Lisans Tezi, İstanbul.

Korkmaz, M. (2005). Duyguların ve Liderlik Stillerinin Öğretmenlerin Performansı Üzerinde Etkisi. Kuram ve Uygulamada Eğitim Yönetimi. Ankara: Pegem A Yayınc1lik. 43, 401-422.

Korkmaz, M.; Çelebi N., Yücel A.S., Şahbudak E., Karta N., Şen, E. (2015). Eğitim Kurumlarında Yönetim ve Liderlik, İstanbul: Nobel Yayınevi.

Korkmaz, M.; Germir, H. N., Şahbudak, E.; Şen, E.; Gürkan, A. ve Kuzucuoğlu, H. A. (2015). Stres, Performans, Verimlilik, İstanbul: Çatı Kitapları.

Küçük, M.(2008). Eğitim Kurumlarında Yöneticilerin Liderlik Davranışlarının Örgüt İklimi Üzerine ve Eğiticilerin Performansına Etkisi, Yüksek Lisans Tezi, Beykent Üniversitesi/İstanbul.

Şanal, M.(2011), Aile İşletmelerinde Kurumsallaşma ve Kurumsal Girişimcilik Üzerine Bir Araştırma, Doktora Tezi, Adana, s. 118.

Şen, E. (2017). Yeni Ekonomi, Yönetim, Nöro-Yönetim ve Senizm, 2.Uluslararası Ekonomi ve Pazar Araştırmaları Kongresi, s.251, Kocaeli.

Şen, E. (2017). Kurumsallaşma ve Kurumsal Yönetişim, İstanbul: Beta Basım Yayım Dağıtım.

Şişman, M. (2004). Öğretim liderliğii. (2. Baskı). Ankara: Pegem A Yayıncılık.

Turan, S. (2002). Teknolojinin Okul Yönetiminde Etkin Kullanımında Eğitim Yöneticisinin Rolü. Eğitim Yönetimi, 30, 271-274.

Yılmaz, K. (2004). Okul Yöneticilerinin Destekleyici Liderlik Davranışları ile Okullardaki Güven Arasındaki İlişki Konusunda İlköğretim Okulu Öğretmenlerinin Görüşleri. İnönü Üniversitesi Eğitim Fakültesi Dergisi, 5(8), 117-131. 


\title{
Leadership Behaviors of School Administrators, Performance Practices and Examination of Teacher Views on Institutionalization in Terms of Various Variables
}

\author{
Erdal ŞEN \\ İstanbul Gelisim University \\ Faculty of Economics, Administrative and \\ Social Sciences \\ İstanbul, Turkey \\ orcid.org/0000-0003-1179-7214 \\ esen@gelisim.edu.tr
}

\author{
Hülya ATEŞOĞLU \\ İstanbul Gelisim University \\ Vocational School \\ İstanbul, Turkey \\ orcid.org/0000-0003-2116-3821 \\ hatesoglu@gelisim.edu.tr
}

\author{
Seda AKDOĞAN \\ orcid.org/000-0002-4944-5671 \\ sedaakdoğan87@hotmail.com
}

\section{Extensive Summary}

\section{Introduction}

In conjuction with economic and technological developments, great social changes and transformations are experienced among today's world. While defining this age, there are various terms used like; Information Age, Internet Age, Technology Age, Informatics Age, Speed Age, Space Age, Nano-technology Age, Genealogy Age, New Economy Age, the Age of Industry 4.0, the Age of Industry 5.0 Age, the Age of Me. These different and new concepts have been constituted with the transition to the new era, resulting from rapid technological advances and changes in social, economical, political, military and socio-cultural areas established and effective changes are observed every day (Şen 2017: 150).

One of the most important factors in this process is the individual; mainly technology; the evaluation and interpretation of the relationship with all relevant variables emerge as an inevitable reality (Şen, 2017: 251). This process, affecting all institutions, also affects educational institutions and structures. This process requires schools to be able to respond to innovations. For this reason, it is very important for the personnel in the school to be united around the organizational goals, the organizational commitment levels are high and even the ones who are responsible for the organization. At this point; school administrators' roles, tasks and managers are becoming increasingly complex. In a rapidly changing environment, administrators will successfully move schools into the next century; school, in the current society and students, teachers, parents, internal and external stakeholders have a very good understanding of the individual, including administrative staff, are expected and improve themselves continuously to provide leadership for the school to be successful. It is important that the managers lead by effective, productive, visionary, motivating, knowledgeable and pioneering leaders for the lifting of many problems in school management and the permanent development of school education. 
Carmeli et al (2006), and Carmeli et al (2006b) in their research, corporate executives, leadership behavior of employees that affect their behavior towards modernity, top management leadership behaviors, they determined that improve the performance of the institution.

School administrators must support teachers and create an environment for selfimprovement. In this way, high performance exhibitions can be achieved by revealing the skills of teachers. If teachers have adopted their principals as leaders; work motivations, satisfaction from their work and integration with the school can easily be achieved (Şişman, 2004).

In order that the performances of the teachers can be high; within the context of performance appraisal studies, situations should be assessed objectively and performance improvement activities should be produced. "Improving the learning conditions and the development of teachers can only be a success with a strong organizational leadership and institutional support," said Karip and Köksal (1996), this idea of "Leadership in terms of contribution to student achievement and other organizational objectives to be achieved are seen as an integral part of effective school concept" (Yilmaz, 2010: 27-28, Shama, Colamaz, 2011: 319-321).

\section{Method}

The purpose of this study is to demonstrate the importance of institutionalization and leadership styles on the performance of teachers in special education institutions. In the study, it is aimed at the importance of institutionalization, what kind of leadership types are and how they affect the processes of institutions, their performance and development of solution proposals.

A total of 133 teachers and administrators working in all branches of a private educational institution in Istanbul have been implemented. Sampling method is preferred when sampling is easy. SPSS 15.0 program was used in the analysis of the data. Demographic information on teachers' gender, age, education status and occupational seniority is presented as frequency and percentage analysis. The Skewness coefficient was used to test the normality of scores on performance practices, leadership approaches and institutionalization practices. It can be interpreted that the scores within \pm 1 of the skewness coefficient used in the normal distribution feature of the continuously variable scores do not show a significant deviation from the normal distribution. In cases where the scores are not normally distributed, normal distribution should be achieved by using square root, logarithmic or inverse transformations in order to use parametric tests (Büyüköztürk, 2011: 40). Because it was determined that the scores did not show a normal distribution in the normality test, logarithmic transformations were used and converted scores were used in $t$ and ANOVA tests. Two independent sample $\mathrm{t}$ tests in comparison with gender, educational status and occupational status; one-way analysis of variance (ANOVA) test. The level of significance in the analyzes was determined as $0.05(\mathrm{p}<0,05)$.

\section{Findings}

In the education system, the school is an important sub-system, and the success of schools is one of the most critical variables for the success of the education system. At this point, school managers at the micro level are a key factor. The school manager's decisions, motivation and work style all affect the process. High motivation in the 
organization will affect the performances of the employees, which will increase the success of the institution.

School administrators need to work to increase the performance of teachers and to grow the institution. Growth is pre-requisite, sustainability. If sustainable growth is prerequisite, it is institutionalized. From this point of view, the aim of this study was to determine the opinions of school administrators about leadership behaviors, performance practices and institutionalization in terms of various variables of teacher opinions.

When the genders of the respondents were examined, it was determined that the number of female participants was higher than male participants. According to this survey, 83 of the 133 people surveyed were female and 50 were female. It may be useful to determine the number of male and female trainers in educational establishments taking into account the needs of the institution. For example, it is thought that it would be beneficial to have a sufficient number of male and female teachers according to their needs in guidance counseling.

When the age of the questionnaire is examined, it can be said that the maximum number of teachers is between 26-30 years. The lowest age range is composed of teachers between the ages of 20-25. Private institutions have a certain experience; it can be observed that young and dynamic workers are preferred more. As Şanal (2011) stated in his work, One of the aims of institutionalization and corporate entrepreneurship activities is the rapid adaptation of innovations to business. Both the efficiency increase and the adaptation to the innovations refer to the concentration of the group of ages 3140 and experience a group that is more experienced than the 20-25 age group, but the young age group supports the work of being open to innovation and expressing that the dynamic structure will be the advantage of enterprises.

When the educational status of the participants is examined, it is determined that the most graduate graduates are in charge. In terms of age criterion, it is considered that the young people are assigned to the educational institutions and thus the graduate students are directed to graduate and doctorate programs. Successful leadership, supportive and participatory leadership behaviors come to the forefront in the leadership behaviors of the managers as the education institutions are formed from high level employees (Küçük, 2008: 88).

According to teacher opinions, the most important leadership approaches are "good communication with the employees", "giving importance to the decisions of the employees positively affecting the organizational commitment", "motivating the rewards according to the talents", "instructional leadership approach being effective in management" and " effectiveness ". According to the teachers, the leadership approaches with the least emphasis were identified as "super leadership", "visionary leadership" and "empowering leadership".

It was found out that the opinions of the administrators regarding the leadership approaches are meaningful in terms of the points of the opinion that the "visionary leadership approach provides management effectiveness". The point average of the opinions of women teachers about the management's visionary leadership approach to management effectiveness is significantly higher than the male teachers' scores. 
According to the teachers' views, the most important institutionalization practices are "to take into account the proposals and demands of the employees, to influence the productivity in the positive direction", "to lead the employees in the change of the basic duty of the management" and "to succeed in the activities of the managers and employees in the power of institutionalization". According to the teachers, institutionalization practices with the least precaution are determined as "not to go out of institutional rules when there is a problem".

The scores of teachers with high scores on opinions on institutionalization practices and the scores on leadership behaviors of managers were also high. It has been found that the teachers who have high scores on the opinions of the managers about the performance applications have high scores on the leadership approaches of the managers.

\section{Conclusion and Discussion}

In order to enable institutions to adapt to rapidly changing and developing world conditions, it is necessary to update all management decision-making and implementation processes by developing new applications and methods that will gain competitive advantage and increase individual and institutional performance. In the realization of this change, the most important source of difference is the element that can create difference. The concept of Stakeholder Management, which covers the processes of evaluating and managing all internal and external stakeholders, has a very important place in terms of the management of the individual. Performance applications should be carried out by considering the needs and wishes of these different personnel working in institutions. These practices should be transformed and managed in a harmonious manner under the direction of students, parents and other groups. On the other hand, in terms of today's business world, institutionalization processes must also be internalized in order to adapt to change and innovation. The level of institutionalization is high; the most important variables of today's world in which institutions that have effective, effective and efficient management and leadership processes, objective implementations that increase the performances of employees and institutions, and institutions that adopt corporate governance principles can have an undeniable power in terms of sustainable growth and development. Both micro and macro level, educational institutions, management of the education system together with all stakeholders; For the individual who is at the head of the most important variables for the future, rapid change and transformation have vital importance in this process. In this context, the management of educational institutions is directly influential in the future and the management of change. 